\title{
First report of the potentially toxic marine diatom Pseudo- nitzschia simulans (Bacillariophyceae) from the East Australian Current
}

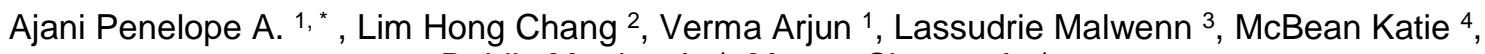 \\ Doblin Martina A. ${ }^{1}$, Murray Shauna A. ${ }^{1}$
}

${ }^{1}$ Climate Change Cluster (C3); University of Technology Sydney; New South Wales, Australia

2 Tunku Abdul Rahman University College; Segamat, Malaysia

3 IFREMER LER-BO, Station de Biologie Marine, Place de la Croix; Concarneau, France

${ }^{4}$ Centre of Expertise Microstructural Analysis; University of Technology; Sydney New South

Wales ,Australia

* Corresponding author : Penelope A. Ajani, email address : penelope.ajani@uts.edu.au

\begin{abstract}
:
Certain species of the marine diatom genus Pseudo-nitzschia are responsible for the production of the domoic acid (DA), a neurotoxin that can bioaccumulate in the food chain and cause amnesic shellfish poisoning (ASP) in animals and humans. This study extends our knowledge by reporting on the first observation of the potentially toxic species Pseudo-nitzschia simulans from this region. One clonal strain of $\mathrm{P}$. simulans was isolated from the East Australian Current and characterized using light and transmission electron microscopy, and phylogenetic analyses based on regions of the internal transcribed spacer (ITS) and the D1-D3 region of the large subunit (LSU) of the nuclear-encoded ribosomal deoxyribonucleic acid (rDNA), as well as examined for DA production as measured by liquid chromatography-mass spectrometry. Although this strain was non-toxic under the defined growth conditions, the results unambiguously confirmed that this isolate is the potentially toxic species $P$. simulans - the first report of this species from the Southern Hemisphere.
\end{abstract}

Keywords : domoic acid, East Australian current, harmful algal blooms, phytoplankton, shellfish 
Pseudo-nitzschia H. Peragallo is a genus of globally distributed, pennate marine diatoms

species which are responsible for the production of domoic acid (DA), the neurotoxin causing amnesic shellfish poisoning (ASP) in seafood consumers and marine organisms (Lelong et al. 2012; Trainer et al. 2012, Bates et al. 2018). Fifty-four species of Pseudo-nitzschia have been identified worldwide thus far, with 26 of these confirmed as DA producers (Bates et al. 2018, Huang et al. 2019). Species belonging to this genus are also a significant component of the phytoplankton community in temperate Australian coastal waters (Ajani et al. 2014). In 2010, a toxic bloom of Pseudo-nitzschia cuspidata (Hasle) Hasle occurred in Wagonga Inlet, south eastern Australia (Ajani et al. 2013a). Although no human illnesses were reported from this event, thirteen samples of farmed Sydney Rock Oysters (Saccostrea glomerata) exceeded regulatory limits for DA (max. concentration of $34 \mathrm{mg} \mathrm{DA} \mathrm{kg}-1$ oyster tissue) and oyster harvesting was suspended for sixteen weeks, causing significant financial loss to the shellfish industry (Ajani et al. 2013a).

Species belonging to this genus are difficult to distinguish with routine microscopy; often multiple lines of evidence (morphological andmolecular) are needed for unequivocal species delineation (Lundholm et al. 2003, 2006, 2012). Since 2012, there have been 18 new Pseudonitzschia species (and one new variety) identified worldwide (Bates et al. 2018 and references therein; Huang et al. 2019), with one of these described from southeastern Australian waters, Pseudo-nitzschia hallegraeffii, Ajani Verma \& Murray (Ajani et al. 2018). There are many regions of the world that have not, however, been assessed for the presence of Pseudo-nitzschia spp., mainly tropical and polar regions, and it is hypothesized that there is significantly more 'cryptic' diversity within this genus to be uncovered (Lundholm et al. 2006, Bates et al. 2018). With this in mind, the aim of our study was to characterize the morphology, molecular and toxicological signature of $P$. simulans isolated from the East Australian Current (EAC) - the 
72 first report of this species aside from its type description from Chinese coastal waters (Li et al. 73 2017).

The EAC originates in the tropical Coral Sea and flows poleward along the edge of the continental shelf, bringing nutrient-depleted, warm tropical waters from the Coral Sea into higher latitudes (Ridgway \& Godfrey 1997). During the austral spring 2016, a scientific expedition commenced on board the Marine National Facility $R V$ Investigator managed by the Commonwealth Scientific and Industrial Research Organization (CSIRO). This oceanographic voyage [IN2016_04] offered a unique opportunity to sample microbial communities at various stations within the EAC.

82

Water samples were collected from station CTD49 on $19 / 09 / 2016\left(27.999^{\circ} \mathrm{S}, 153.780^{\circ} \mathrm{E}\right.$,

Station CTD49, Supplementary Table 1 and Supplementary Fig. 1). This sampling station was situated $33 \mathrm{~km}$ offshore (bottom depth $100 \mathrm{~m}$ ), adjacent to the coastal area of the Gold Coast, south of Brisbane, Australia. The environmental data and water mass characteristics at the time of sampling at this location are summarized in Supplementary Table 2. One non-axenic clonal culture of Pseudo-nitzschia (Strain CTD49_1) was established by single cell isolation using a drawn-out Pasteur pipette from a $25 \mu \mathrm{m}$ net haul sample (245 mm diameter, $1.2 \mathrm{~m}$ length net) collected from $20 \mathrm{~m}$ (depth to the surface) at this station. After initial isolation into a 24 multi-

91 well culture plate (Corning Inc. Durham, USA) containing $1 \mathrm{~mL}$ of $\mathrm{f} / 2$ media (Guillard 1975),

92 the clean strain was transferred to a $50 \mathrm{ml}$ culture flask (Thermo Fisher Scientific, Australia, 93 Pty.) also containing $\mathrm{f} / 2$ media, and placed in an incubator set at $18^{\circ} \mathrm{C}$ under a photon flux of $9460 \pm 15 \mu \mathrm{mol}$ photons $\mathrm{m}^{-2} \mathrm{~s}^{-1}$ (TLD 18W/54 fluorescent tubes, Philips, color temperature $10,000 \mathrm{~K}$ ) and a 12/12 hour dark/light cycle. The remaining net haul sample was fixed with

96 Lugol's iodine and stored prior to microscopic examination of the phytoplankton community 
97

119 For ITS analyses, the dataset comprised 164 sequences with 4 sequences from Nitzschia navis-

composition. On day 14 (late stationary phase) Pseudo-nitzschia cells were sub-sampled for light (LM) and transmission electron microscopy (TEM), DNA sequencing of inter transcribed spacer (ITS), 5.8S and large ribosomal subunit gene regions (D1-D3), as well as DA production as measured by liquid chromatography-mass spectrometry (LC-MS/MS).

The length and width of 45 individual valves were measured using a maximum magnification of $\times 1000$ under an Eclipse Ci microscope (Nikon, Tokyo, Japan) equipped with an Infinity 31c digital camera (Lumenera, Ottawa, Canada). For TEM, $20 \mathrm{ml}$ of sample was preserved in Lugol's iodine prior to cleaning using the method of Hasle \& Fryxell (1970). Once cleaned, samples were placed on formvar-coated copper grids and examined using FEI Tecnai T20 TEM (LaB6, Hillsboro, OR, USA), operated at high tension of 120kV equipped with a 894 CCD 2k $\times 2 \mathrm{k}$ camera (Gatan Inc., Pleasanton, CA, USA). All images were analysed using Image $\mathbf{J}$ software v1.52A (http://rsbweb.nih.gov/ij/), and the morphometric diagnoses for the structure of Pseudo-nitzschia were guided according to Lundholm et al. (2003, 2012).

Methods for DNA extraction, polymerase chain reaction and sequencing are detailed in Verma et al. (2016). Sequences obtained in this study were then analyzed phylogenetically. A total of 139 sequences were compiled and used for analyzing the LSU dataset, in which 5 sequences were assigned as outgroups (Nitzschia frustulum, N. navis-varingica (two sequences), $N$. pellucida and Bacillaria paxillifer). Sequence data obtained from the present study and those retrieved from NCBI were analyzed as in Lim et al. (2018). varingica (three sequences) and $N$. longissimi set as outgroups. The conserved secondary structure was modelled using ITS2 sequences as detailed in Lim et al. (2018) as well as the 
122 phylogenetic analyses. MP trees represented a better tree topology for both LSU and ITS2

123 analyses and are shown in Fig. 2 and Supplementary Fig. 2.

125 For analysis of cellular DA content, fifty $\mathrm{ml}$ of culture $\left(6 \times 10^{4}\right.$ cells $\left.\mathrm{mL}^{-1}\right)$ was harvested in 126 the late stationary phase by centrifugation at $1500 \mathrm{~g}$ for $5 \mathrm{~min}$, the pellet was freeze dried, 127 frozen at $-80^{\circ} \mathrm{C}$ and transported to the Sydney Institute of Marine Science for DA extraction 128 (McNabb et al. 2005). The pellet was dried down under nitrogen (flow) and re-suspended in $50 \mu \mathrm{L}$ of $90 \% \mathrm{MeOH}$. The solution was then vortexed for $1 \mathrm{~min}$, sonicated for $1 \mathrm{~min}$, and

130 centrifuged for $5 \mathrm{~min}$ at $2283 \mathrm{~g}$. The supernatant was subsequently used for LC-MS/MS analysis (Thermo Scientific Q Exactive, Waltham, MA, USA) and compared to both spiked and standard samples. DA was reported as $\mathrm{ng} / \mathrm{mL}$ with a detection limit of $0.1 \mathrm{ng} / \mathrm{mL}$.

134 The phytoplankton community at station CTD49 on 19/9/2016 was dominated by the diatom taxa Pseudo-nitzschia spp., Guinardia striata, Chaetoceros spp., Lauderia annulata, and an 136 unidentified coccolithophore. Morphological identification using LM and TEM (Table 1, Fig 2A-E) of strain CTD49_1 unequivocally confirmed this as the first report of $P$. simulans in Australian waters. Cells were lanceolate and slightly asymmetrical in valve view with the presence of a central interspace (Fig. 1A-C). Cells had an apical axis of 26.9-40.0 $\mu \mathrm{m}(\mathrm{n}=45)$

140 and transapical axis of 1.9-2.8 $\mu \mathrm{m}(\mathrm{n}=45)$ (Table 1). Valves were tapering towards the ends 141 with truncated apices (Fig. 1D). The fibulae were regularly spaced with a density of 19-25 per $14210 \mu \mathrm{m}$ and $37-40$ interstriae per $10 \mu \mathrm{m}(\mathrm{n}=15)$. Striae contained one row of rounded poroids, each with hymen divided mainly into 2 with rarely 5 sectors located at margins of the sectors

144 (Fig. 1B-C) (see Fig. 6 Li et al. 2017). Within the striae, poroid density ranged from 5-7 per 1 $\mu \mathrm{m}$ (Table 1). Two cingular bands were observed both having a striae density ranging from

146 44-48 per $10 \mu \mathrm{m}$ (Fig. 1E, Table 1). The valvocopula had a poroid arrangement of 1-2 rows 
147 wide and 1-2 rows high per stria while the second band had a striae structure of 2 rows wide

148 and 1 row high (Fig. 1E, Table 1).

150 There appeared to be little morphological variation in strain CTD49_1 with the type specimens

151 isolated by Li et al. (2017) from Chinese coastal waters, with the notable exception that cells

152 from China were longer (mean length of $43.2 \mu \mathrm{m}$ compared to $35.3 \mu \mathrm{m}$ in the present study)

153 and narrower $(1.9 \mu \mathrm{m}$ compared to $2.3 \mu \mathrm{m})$, although this may not be a very informative

154 variation. There was also a minor variation in the valvocopula striae structure, whereby the

155 cells observed in the present study varied in their structure from 1-2 poroid wide to 1-2 poroid

156 high, and those from $\mathrm{Li}$ et al. reported a $2 \times 2$ structure (Table 1). Further observations are

157 needed to validate this morphological variability between different populations of $P$. simulans.

159 The final partial LSU rDNA alignment was 543 nucleotides in length while the ITS2 rDNA

160 alignment, based on secondary structural information, was 680 nucleotides in length. The best

161 evolutionary models calculated for LSU (ML and BI) was General Time Reversible (GTR) +I

$162+\mathrm{G}$ while ITS2 (BI) was Transitional model (TIM2) $+\mathrm{I}+\mathrm{G}$. Phylogenetic analyses of the LSU

163 and ITS2 regions covered $41(78.8 \%)$ and $47(90.3 \%)$ of the presently known 52 Pseudo-

164 nitzschia species further supporting the morphological identification of $P$. simulans

165 (Supplementary Table 3). The phylogenetic trees based on both gene regions, ITS2 and partial

166 LSU (Fig $2 \&$ Supplementary Fig. 2) are shown. While P. simulans formed a less supported

167 monophyletic clade in LSU tree with $P$. hallegraeffii, $P$. dolorosa and $P$. micropora

168 (Supplementary Fig. 2), it formed a strongly supported clade in the phylogeny based on the

169 ITS2 gene (MP/ML/BI: 81/100/0.94), sister to P. dolorosa, $P$. bucculenta and $P$. hallegraeffii

170 (Fig. 2). Interestingly, P. simulans was well separated into two subclades in the ITS2 tree (Fig.

171 2), with similar topologies also observed in Li et al. (2017) and Lim et al. (2018). When the 
172 ITS2 secondary structures were examined, strains CTD49_1, MC984 and MC3038 in subclade

173 I revealed the presence of 4 hemi compensatory base changes (HCBCs) when compared to 174 strains MC281, MC282 and MC940 subclade II. One was found at helix I (U-G↔U-A), three

175 at helix III (one G-C↔G-U and two G-U↔G-C) and 8 single nucleotide polymorphisms. With 176 the presence of cryptic and pseudo-cryptic species within the genus Pseudo-nitzschia, mating 177 experiments would be crucial to further clarify the identity of $P$. simulans subclades I and II.

179 Under laboratory conditions strain CTD49_1 did not produce DA. Similarly, analyses of $P$. 180 simulans from Chinese coastal waters identified DA in one out of five strains tested, albeit at 181 a very low concentration of $1.54 \mathrm{fg} \mathrm{DA} \mathrm{cell}^{-1}$ (Li et al. 2017). These results suggest that $P$. 182 simulans is not a significant threat to marine life, aquaculture or human health. The production 183 of DA under culture conditions however, can vary over the growth cycle and is not always representative of DA production in situ, and large intra- and inter-species variability in Pseudonitzschia DA production have been reported in the literature (Sauvey et al. 2019 and references therein). A range of abiotic and biotic factors including species growth phase, nutrie nt

187 availability, bacterial associations, the presence of grazers and/or allelopathic effects etc. have

188 been demonstrated to influence DA production in Pseudo-nitzschia species, but the exact trigger(s) remain elusive (Bates et al. 2018).

A total of twenty-one species of Pseudo-nitzschia have now been characterized from Australian

192 coastal waters, with four confirmed as DA producers: P. australis, P. multistriata, P. cuspidata

193 and P. delicatissima (Hallegraeff 1994; Lapworth et al. 2001; Jameson and Hallegraeff 2010; 194 Ajani et al. 2013a, 2013b, Ajani et al. under review) (Supplementary Table 4). While only one 195 of these taxa P. cuspidata has been observed to produce significant concentration of DA in the 196 laboratory (24.5 pg DA per cell; Ajani et al 2013a), high abundances of Pseudo-nitzschia in 
197 field samples around in south eastern Australia would suggest that this genus continues to pose

198 a threat. Evidence for this was revealed with an unprecedented toxic bloom of $P$. delicatissima 199 (the first report of this species in the southern hemisphere) in March 2018 in the Hawkesbury 200 River, an important oyster growing estuary in this region (Ajani et al. under review). The 201 results of a modelling study indicated that this bloom most likely resulted from an increase in 202 soluble reactive phosphorus (in an estuary where nitrogen loading is already high) (Ajani et al. 203 under review). Further hidden diversity, an increase reliance on aquaculture, and an increase 204 in urbanization and associated nutrient inputs along this coastline, suggest that this toxic genus 205 should be a significant research focus into the future.

\section{ACKNOWLEDGEMENTS}

208 The authors would like to thank Australia's Marine National Facility for sea time on board the 209 RV Investigator, management of the vessel and support of the IN2016_V04 voyage by MNF 210 staff at CSIRO, and all of the officers and crew on board. The authors would also like to thank

211 Dr Chowdhury Sarowar from the Sydney Institute of Marine Science for DA analysis. PA 212 would also like to thank the University of Technology Sydney Chancellor's Postdoctoral 213 Fellowship scheme for funding.

\section{REFERENCES}

216 Ajani, P., Murray, S., Hallegraeff, G. et al. 2013a. The diatom genus Pseudo-nitzschia (Bacillariophyceae) in New South Wales, Australia: morphotaxonomy, molecular phylogeny, toxicity, and distribution. Journal of Phycology, 49: 765-785.

Ajani, P., Murray, S., Hallegraeff, G., Brett, S. and Armand, L. 2013b. First reports of Pseudonitzschia micropora and P. hasleana (Bacillariaceae) from the Southern Hemisphere: 
Morphological, molecular and toxicological characterization. Phycological Research, 61: 237-248.

Ajani, P. A., Allen, A. P., Ingleton, T. and Armand, L. 2014. A decadal decline in relative abundance and a shift in microphytoplankton composition at a long-term coastal station off southeast Australia. Limnology and Oceanography, 59: 519-531.

Ajani, P. A., Verma, A., Lassudrie, M., Doblin, M. A. and Murray, S. A. 2018. A new diatom species $P$. hallegraeffii sp. nov. belonging to the toxic genus Pseudo-nitzschia (Bacillariophyceae) from the East Australian Current. Plos One, 13(4): e0195622.

Bates, S. S., Hubbard, K. A., Lundholm, N., Montresor, M. and Leaw, C. P. 2018. Pseudonitzschia, Nitzschia, and domoic acid: New research since 2011. Harmful Algae, 79: 343.

Guillard, R. R. L. 1975. Culture of phytoplankton for feeding marine invertebrates. In W.L., S. and M.H., C. (Eds) Culture of Marine Invertebrate Animals. Plenum Press, New York, USA., pp. 26-60.

Hallegraeff, G. M. 1994. Species of the Diatom Genus Pseudo-nitzschia in Australian Waters. Botanica Marina, 37: 397-411.

Hasle, G. R. and Fryxell, G. A. 1970. Diatoms: Cleaning and mounting for light and electron microscopy. Transactions of the American Microscopical Society., 89: 469-474.

Huang, C.X., Dong, H. C., Lundholm, N. et al. 2019. Species composition and toxicity of the genus Pseudo-nitzschia in Taiwan Strait, including P. chiniana sp. nov. and P. qiana sp. nov. Harmful Algae, 84: 195-209.

Jameson, I. and Hallegraeff, G. M. 2010. Planktonic Diatoms. .Algae of Australia: 
phytoplankton of temperate coastal waters. pp. 16-82.

247 Lapworth, C., Hallegraeff, G. and Ajani, P. 2001. Identification of domoic-acid-producing Pseudo-nitzschia species in Australian waters. Proceedings of the Ninth International Conference on Harmful Algal Blooms. Intergovernmental Oceanographic Commission of UNESCO, Paris, pp. 38-41.

Lelong, A., Hegaret, H., Soudant, P. and Bates, S. S. 2012. Pseudo-nitzschia (Bacillariophyceae) species, domoic acid and amnesic shellfish poisoning: revisiting previous paradigms. Phycologia, 51: 168-216.

Li, Y., Huang, C. X., Xu, G. S. et al. 2017. Pseudo-nitzschia simulans sp. nov. (Bacillariophyceae), the first domoic acid producer from Chinese waters. Harmful Algae, 67: 119-130.

Lim, H. C., Tan, S. N., Teng, S. T. et al. 2018. Phylogeny and species delineation in the marine diatom Pseudo-nitzschia (Bacillariophyta) using cox1, LSU and ITS2 rRNA genes: a perspective in character evolution. Journal of Phycology, 54: 234-248.

Lundholm, N., Bates, S. S., Baugh, K. A. et al. 2012. Cryptic and pseudo-cryptic diversity in diatoms-with descriptions of Pseudo-nitzschia hasleana sp. nov. and P. fryxelliana sp. nov. J Phycol, 48: 436-54.

Lundholm, N., Moestrup, O., Hasle, G. R. and Hoef-Emden, K. 2003. A study of the Pseudonitzschia pseudodelicatissima/cuspidata complex (Bacillariophyceae): What is $P$. pseudodelicatissima? Journal of Phycology, 39: 797-813.

Lundholm, N., Moestrup, O., Kotaki, Y., Hoef-Emden, K., Scholin, C. and Miller, P. 2006. Inter- and intraspecific variation of the Pseudo-nitzschia delicatissima complex (Bacillariophyceae) illustrated by rRNA probes, morphological data and phylogenetic analyses. Journal of Phycology, 42: 464-481.

270 Mcnabb, P., Selwood, A. I. and Holland, P. T. 2005. Multiresidue method for determination of 
algal toxins in shellfish: single-laboratory validation and interlaboratory study. Journal of AOAC International, 88: 761-772.

273 Ridgway, K. R. and Godfrey, J. S. 1997. Seasonal cycle of the East Australian Current. Journal of Geophysical Research-Oceans, 102: 22921-22936.

Sauvey, A., Claquin, P., Le Roy, B., Gac, M. L. and Fauchot, J. Differential influence of life cycle on growth and toxin production of three Pseudo-nitzschia species (Bacillariophyceae). Journal of Phycology, 55(5): 1126-1139.

Trainer, V. L., Bates, S. S., Lundholm, N. et al. 2012. Pseudo-nitzschia physiological ecology, phylogeny, toxicity, monitoring and impacts on ecosystem health. Harmful Algae, 14: 271-300.

281 Verma, A., Hoppenrath, M., Dorantes-Aranda, J. J., Harwood, D. T. and Murray, S. A. 2016. Molecular and phylogenetic characterization of Ostreopsis (Dinophyceae) and the description of a new species, Ostreopsis rhodesae sp. nov., from a subtropical Australian lagoon. Harmful Algae, 60: 116-130. 
285 Table 1. Morphological information pertaining to the type strain of Pseudo-nitzschia simulans (Li et al. 2017) and the strain collected in this

286 study (CTD49_1). Note: $\mathrm{n}=$ number of specimens observed; data are given as minimum and maximum range (above) and mean \pm SD (below);

287 \#=no. poroids wide $\times$ no. poroids high - valvocopula pattern; followed by band II pattern below.

\begin{tabular}{|c|c|c|c|c|c|c|c|c|c|c|}
\hline $\begin{array}{l}\text { Species/ } \\
\text { Strain ID }\end{array}$ & Valve Shape & $\begin{array}{c}\text { Central } \\
\text { interspace }\end{array}$ & $\begin{array}{c}\text { Apical } \\
\text { Axis }(\mu \mathrm{m})\end{array}$ & $\begin{array}{c}\text { Transapical } \\
\text { Axis }(\mu \mathrm{m})\end{array}$ & $\begin{array}{l}\text { Interstriae } \\
\text { per } 10 \mu \mathrm{m}\end{array}$ & $\begin{array}{c}\text { Fibulae per } \\
10 \mu \mathrm{m}\end{array}$ & $\begin{array}{l}\text { Rows of } \\
\text { Poroids }\end{array}$ & $\begin{array}{c}\text { Poroids per } \\
1 \mu \mathrm{m}\end{array}$ & $\begin{array}{c}\text { Band Striae } \\
\text { per } 10 \mu \mathrm{m}\end{array}$ & $\begin{array}{l}\text { Band Striae } \\
\text { Structure\# }\end{array}$ \\
\hline CTD49_1 & $\begin{array}{c}\text { lanceolate, } \\
\text { as ymmetrical/ } \\
\text { symmetrical }\end{array}$ & + & $\begin{array}{c}26.9-40.0 \\
(35.3 \pm 2.8) \\
(n=45)\end{array}$ & $\begin{array}{c}1.9-2.8 \\
(2.3 \pm 0.2) \\
(\mathrm{n}=45)\end{array}$ & $\begin{array}{c}37-40 \\
(38.9 \pm 1.1) \\
(n=15)\end{array}$ & $\begin{array}{c}19-25 \\
(21.5 \pm 1.7) \\
(\mathrm{n}=15)\end{array}$ & 1 & $\begin{array}{c}5-7 \\
(6.0 \pm 0.6) \\
(n=6)\end{array}$ & $\begin{array}{c}44-48 \\
(46.8 \pm 1.8) \\
(n=5)\end{array}$ & $\begin{array}{c}1-2 \times 1-2(\mathrm{n}=5) \\
2 \times 1(\mathrm{n}=5)\end{array}$ \\
\hline P. simulans & $\begin{array}{l}\text { lanceolate/ } \\
\text { sigmoidal in } \\
\text { girdle view }\end{array}$ & + & $\begin{array}{c}37-49 \\
(43.2 \pm 5.4) \\
(n=30)\end{array}$ & $\begin{array}{c}1.8-2.1 \\
(1.9 \pm 0.1) \\
(n=25)\end{array}$ & $\begin{array}{c}34-44 \\
37 \pm 3 \\
(n=30)\end{array}$ & $\begin{array}{c}19-23 \\
21 \pm 2 \\
(n=30)\end{array}$ & 1 & $\begin{array}{c}5-7 \\
(6 \pm 1) \\
(n=30)\end{array}$ & $\begin{array}{l}40-55 \\
(47 \pm 4) \\
(n=12)\end{array}$ & $2 \times 2$ \\
\hline
\end{tabular}

288 


\section{List of Figures}

290 Figure 1. Transmission electron micrographs of Pseudo-nitzschia simulans isolated from the 291 East Australian Current. A) whole valve (scale bar $5 \mu \mathrm{m}$ ); B-C) mid-valve, showing central 292 interspace and one row of poroids with sectors (scale bars $0.5 \mu \mathrm{m}$ ); D) valve tip with truncated 293 apice (scale bar $1 \mu \mathrm{m}$ ); E) V, II, III indicate valvocopula, second and third bands respectively, 294 showing poroid structure of one or two poroids wide and one or two poroids high (scale bar 1 $295 \mu \mathrm{m})$.

296

297 Figure 2. Pseudo-nitzschia spp. MP tree based on ITS2 region inferred from sequence-

298 structure information. MP/ML bootstrap values $\geq 80 \%$ and $\mathrm{BI}$ posterior probabilities (PP) $\geq$ 2990.80 are shown. Thick lines represent MP/ML/BI of $100 \%$ (bootstrap) and 1.00 (PP). 
301 List of Supplementary Figures

302 Supplementary Figure 1. Map showing the location of station CTD49 sampled on 19 303 September $2016\left(27.999{ }^{\circ} \mathrm{S}, 153.780{ }^{\circ} \mathrm{E}\right.$ at 19:26 UTC). Figure compiled with the average

304 highest available quality sea surface temperature data from 14 to 19 September 2016 (NOAA30519 MOS - SRS Satellite - SST L3S - 06 day composite - day and night time composite) and 306 eastward geostrophic current velocity data from 17 to 19 September 2016 (IMOS -

307 OceanCurrent - Gridded sea level anomaly - Near real time) (IMOS, 2016a and b).

308

309 Supplementary Figure 2. Pseudo-nitzschia spp. MP tree based on LSU D1-D3 region.

310 MP/ML bootstrap values $\geq 85 \%$ and $\mathrm{BI}$ posterior probabilities $(\mathrm{PP}) \geq 0.90$ are shown. Thick

311 lines represent MP/ML/BI of 100\% (bootstrap) and 1.00 (PP). 